\title{
Mechanism in Using Commercial High Efficient Zeolite-Base Greenfeed Slow Release Fertilizers
}

\author{
Tan Yu Wea, Muhamad Nizam Amahd Unonis, Muhamad Izzuddin Khairuddin, \\ Shahirulikram Shaharuddin, Ng Chang Chai*
}

Technical and Research Department, Greenfeed Agro SdnBhd, Kuala Lumpur, Malaysia

Email: *ccng@greenfeed.com.my

How to cite this paper: Tan, Y.W., Unonis, M.N.A., Khairuddin, M.I., Shaharuddin, S. and Ng, C.C. (2018) Mechanism in Using Commercial High Efficient ZeoliteBase Greenfeed Slow Release Fertilizers. Journal of Agricultural Chemistry and Environment, 7, 1-9.

https://doi.org/10.4236/jacen.2018.71001

Received: December 20, 2017

Accepted: January 22, 2018

Published: January 25, 2018

Copyright $\odot 2018$ by authors and Scientific Research Publishing Inc. This work is licensed under the Creative Commons Attribution International License (CC BY 4.0).

http://creativecommons.org/licenses/by/4.0/

\begin{abstract}
Fertilizer issues such as overuse, leaching and soil degradation are becoming severe in worldwide plantation areas. To secure current food production, prevention measures on these issues are relatively limited on agricultural production areas. Slow release fertilizer is prevailing over past years due to its significant effects on prevention of fertilizer leaching and less harm to soil and underground water. We presented here the mechanisms of a novel zeolite-based slow release fertilizer including its properties as reservoirs of nutrients, $\mathrm{pH}$ balancer and also water retainer in soil. By providing sufficient nutrients to soil, this fertilizer has commercially proven to give better growing environment to grower as well as labor saving and cost saving.
\end{abstract}

\section{Keywords}

Ion Gradient, Slow Release Fertilizer, Soil, Zeolite

\section{Introduction}

To meet the requirements on food demands, elements such as nitrogen and phosphorus and potassium in fertilizer are essential for living crops. Global consumption on fertilizer is steadily increasing in response to the growing population and this has led to overuse of fertilizers in many areas [1]. Leaching of nitrate can happen through inappropriate use of nitrogen fertilizers and become a major cause of soil acidification, degradation and underground water pollution [2] [3]. The need to seek high efficient utility rate of commercial fertilizer is very much stronger over years. So far, the appearance of controlled release fertilizer, or the so-called time-release fertilizer has improved the nutrients use efficiency [4], however, these resin-coated or polymer-coated fertilizers may cause some other environmental issues due to the resin waste remained after nutrients re- 
leased and also, temperature-regulated characteristic of these fertilizers is always a restriction factor to its release.

Zeolite is a group of highly crystalline hydrated aluminosilicate minerals with porous structure with diameters of pore between $0.3-1 \mathrm{~nm}$ [5] [6] [7]. It is widely used as molecular sieve materials that can absorb ions based on their sizes [7] [8]. This enables zeolite to retain cation elements such as $\mathrm{NH}^{4+}, \mathrm{K}^{+}, \mathrm{Ca}^{2+}$ and so on [7]. The release of adsorbed cations on the surface zeolites due to ionic gradient in soil ensures its slow-release characteristics [9] [10] [11]. The use of zeolite-based fertilizer has been reported in crops such as paddy and banana [12] [13].

Commercial zeolite-regulated slow release fertilizer presented by Greenfeed Agro Company in Malaysia has made significant progress over years in global market. Greenfeed ${ }^{\circledR}$ slow release fertilizer (GSRF), a compressed and pelletized nugget forming in averagely $16 \mathrm{~g}$ per piece, has the absorptive mechanism that plays a definitive role to the nutrient release and availability for plant's utility (Figure 1). This specialty compound fertilizer is zeolite integrated to prevent nutrient losses, regulate cations exchange capacity (CEC) in soil and also preservation of water [10] [11] [14]. Moreover, zeolite is also helping to improve $\mathrm{pH}$ level, while the slight-alkaline nature of Greenfeed slow release fertilizer contains liming materials which is able to optimize the soil $\mathrm{pH}$ around the applied area. We summarized here the mechanism may involve on the performance of this high efficient slow release fertilizer.

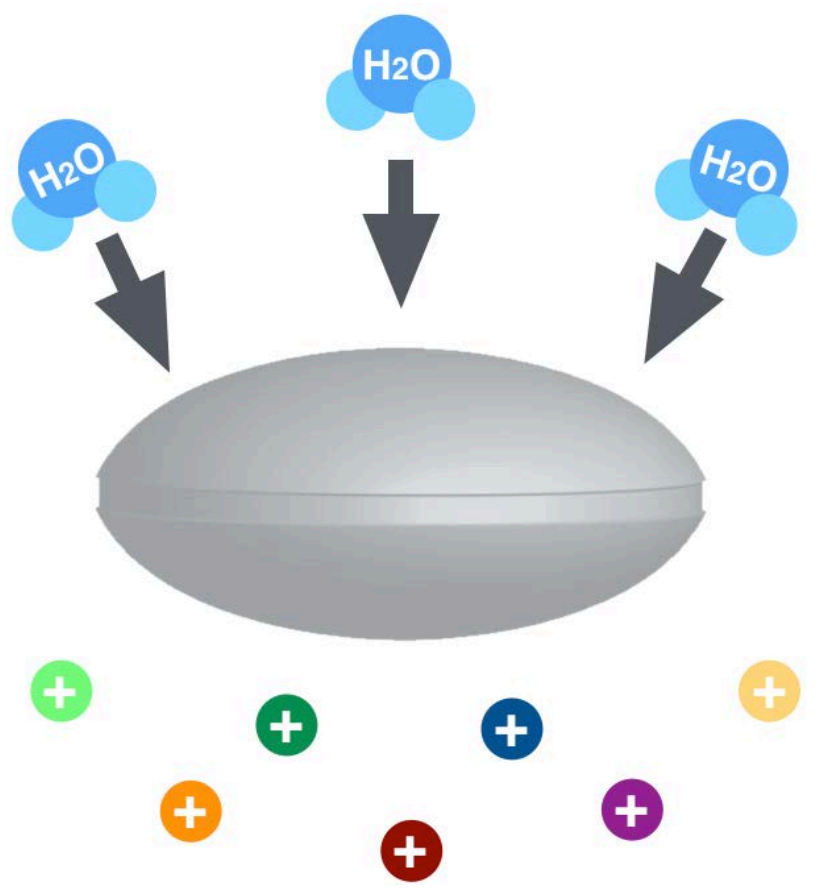

Figure 1. Schematic diagram on the Greenfeed ${ }^{\circledR}$ Slow Release Fertilizer release mechanisms. Water first into contact with the nugget. The outer layer then will start releasing nutrients into the soil environment based on the ionic gradient. 


\section{Reservoir and Release of Elements by Ionic Gradient}

Zeolite is natural occurring mineral known as a suite of porous, fine-grained minerals commonly found in certain near surface, sediment rocks, having special physical and chemical properties that could make them valuable for agricultural practices [10] [11]. Some of the characteristics of zeolites that potentially make them desirable for improving the properties of soils are a large internal porosity that results in water retention, a uniform particle-size distribution that allows them to be easily incorporated, and high cation-exchange capacity that retains nutrients [15]. Abdi [16] reported that zeolite capabilities on the improvement of soil physical environment particularly in sandy and clay poor soil. This report also stated that the application of zeolite increased the available nitrogen, phosphorus, calcium and magnesium of the soil. Other study also proves that by using zeolite as soil amendment will improve the soil cation exchange capacity as stated by DeSutter and Pierzynski [17]. Zeolite also has a positive influence on nitrate leaching, nitrogen use efficiency and yield of crop [18]. The benefits of slow release fertilizer are not just limited to nitrogen alone. It also applies to other nutrient as well. As an example, Bley et al. [19] also proved the positive impact of potassium (K) slow release fertilizer.

The activated zeolite included within GSRF's formulation provides the lasting nutrient reservoirs through the adhesive characteristic that zeolite has; resulting in longer period of nutrient availability for the plant's uptake. The nutrient release is carried out according to the ionic gradient difference between the fertilizer and the soil. This will ensure that the nutrient released is being carried out synergistically to the soil environment surrounding the fertilizer, which is relatively affected by the root's absorption rate. Such process promotes the efficient nutrient release into the soil and based on the plant demand. The breakdown of GSRF in soil is summarized into three directive processes, which are rehydration, reactivation and equivalence control. The rehydration process is the movement of soil moisture to the surface of the fertilizer. After the hydration process taken, nutrients are reactivated and turn into ionic form and ready to be released from the zeolite carrier. The third equivalence process occurs based on the ionic gradient within the fertilizer and the soil. The nutrients are released via transfusion based on the differences in the ionic gradient between the fertilizer and the soil, hence, resulting in a controlled and efficient nutrient releasing mechanisms that defines this high efficient fertilizer. Its performance on crops such as banana and paddy were reported by $\mathrm{Ng}$ et al. In banana applied GSRF, the foliar content of macro-elements nitrogen, phosphate, and potassium in Greenfeed ${ }^{\circledR}$ group was $12.5 \%, 10 \%$ and $34.8 \%$, respectively, higher than the conventional compound fertilizers and photosynthesis rate was found $10.5 \%-32 \%$ higher [12]. Paddy yield was found increased from $6100 \mathrm{~kg} / \mathrm{ha}$ to $8000 \mathrm{~kg} / \mathrm{ha}$, with $33 \%$ increment [13].

\section{3. pH Balancer}

Leaching of nitrogen in the nitrate form is a very important factor in soil acidity. 
Nitrate is a major nutrient for plant growth however, wastage of fertilizer from this processes are tremendous [20]. When there are more nitrates than the plant can use, the nitrate is at risk of leaching below the plants roots and into the ground water system. Every nitrogen element that cannot be absorbed by the plant will potentially leach and bring down the soil $\mathrm{pH}$ [21]. Leaching of nitrate can happen through inappropriate use of nitrogen fertilizers and intensive production of crops that required heavy applications of nitrogen fertilizers are examples of practices that may increase the risk of nitrate leaching. Hence, proper fertilizer selection and proper practice are crucial for minimize this issue. Leaching losses is high in poor soil with low clay content. Table 1 shows the summary of the nitrogen fertilizer loss in different type of soil presented by Foong [22].

Numerous studies have shown that the application of slow release fertilizer can significantly reduce the amount of nutrient leaching. Nitrogen is one of the nutrients that are most prone to leaching. Nitrogen leaching into groundwater poses serious environmental hazards that result from the lack of oxygen available to organisms [23]. Zareabyaneh \& Bayatvarkeshi [20] shows that the application of slow release fertilizer reduces the nitrate leaching improve nitrogen use efficiency and increase yield production. Slow release fertilizers reduce nitrate leaching up to $35.75 \%$ and increase plant available nitrogen in the soil during growing season [20]. Uptake and assimilation of $\mathrm{NH}^{4+}$ is a proton generating process and usually leads to a decrease in the external $\mathrm{pH}$ and in the contents of carboxylates in the roots, whereas $\mathrm{NO}^{3-}$ uptake and assimilation is a protonconsuming process and usually leads to an increase in external $\mathrm{pH}$ and in the contents of carboxylates in the roots [24]. Hence, the cytoplasmic $\mathrm{pH}$ must be maintained in a fairly constant at or near neutral $\mathrm{pH}$, in order not to disrupt the cellular processes which are sensitive to $\mathrm{pH}$ [25] [26].

Many research and studies has indicated the use of zeolite can improve $\mathrm{pH}$ level of acid soils, thus reducing the need for applications of lime. Apart from that, GSRF has a slight-alkaline characteristic that derived from the liming material contained within that have the ability to improve the soil $\mathrm{pH}$ around the applied area. Table 2 and Figure 2 demonstrate the effect of using GSRF on soil $\mathrm{pH}$ over a period of 9 years. The soil $\mathrm{pH}$ was gradually improved (internal study not published). Problem like soil hardening also much altered. The lower

Table 1. Percentage of nitrogen leaching in different type of soil.

\begin{tabular}{cccc}
\hline Soil group & Soil situation & $\begin{array}{c}\text { Leaching losses \% nutrient } \\
\text { lost in fertilizer }\end{array}$ & $\begin{array}{c}\text { Balance \% nutrient } \\
\text { available to oil palm }\end{array}$ \\
\hline $\mathbf{1}$ & Clayey > 8\% slope & 10 & 50 \\
$\mathbf{2}$ & Sandy $>8 \%$ slope & 43 & 29 \\
$\mathbf{3}$ & Clayey $>$ 8\% slope & 10 & 60 \\
$\mathbf{4}$ & Sandy $>8 \%$ slope & 43 & 38 \\
$\mathbf{5}$ & Peat & 56 & 29 \\
\hline
\end{tabular}


Table 2. Data on the average $\mathrm{pH}$ reading of six different planting ages of oil palm in Malaysia.

\begin{tabular}{cccccccccc}
\hline $\begin{array}{c}\text { Planting } \\
\text { year }\end{array}$ & $\begin{array}{c}\mathrm{pH} \\
\text { value } \\
(\mathbf{2 0 0 3})\end{array}$ & $\begin{array}{c}\mathrm{pH} \\
\text { value } \\
(2004)\end{array}$ & $\begin{array}{c}\mathrm{pH} \\
\text { value } \\
(\mathbf{2 0 0 5 )}\end{array}$ & $\begin{array}{c}\mathrm{pH} \\
\text { value } \\
(2006)\end{array}$ & $\begin{array}{c}\mathrm{pH} \\
\text { value } \\
(2007)\end{array}$ & $\begin{array}{c}\mathrm{pH} \\
\text { value } \\
(2008)\end{array}$ & $\begin{array}{c}\mathrm{pH} \\
\text { value } \\
(2009)\end{array}$ & $\begin{array}{c}\mathrm{pH} \\
\text { value } \\
(2010)\end{array}$ & $\begin{array}{c}\mathrm{pH} \\
\text { value } \\
(2011)\end{array}$ \\
\hline $\begin{array}{c}2000 \\
\text { (S. Clay. S) }\end{array}$ & 4.92 & 6.08 & 5.90 & 5.80 & 5.60 & 5.90 & 5.90 & 6.10 & 6.15 \\
$\begin{array}{c}2002 \\
\text { (Sandy. S) }\end{array}$ & 4.23 & 5.34 & 5.45 & 5.40 & 5.50 & 5.56 & 5.40 & 5.70 & 5.80 \\
$\begin{array}{c}2005 \\
\text { (Peat. S) }\end{array}$ & 3.73 & 4.00 & 4.30 & 4.50 & 4.70 & 4.70 & 4.80 & 4.90 & 4.80 \\
$\begin{array}{c}2006 \\
\text { (Peat. S) }\end{array}$ & 4.38 & 4.50 & 4.70 & 4.60 & 4.80 & 4.90 & 4.87 & 4.90 & 4.85 \\
$\begin{array}{c}\text { 2006 } \\
\text { (Aluvir. S) }\end{array}$ & 4.22 & 5.32 & 5.47 & 5.50 & 5.45 & 5.50 & 5.44 & 5.60 & 5.70 \\
\hline
\end{tabular}

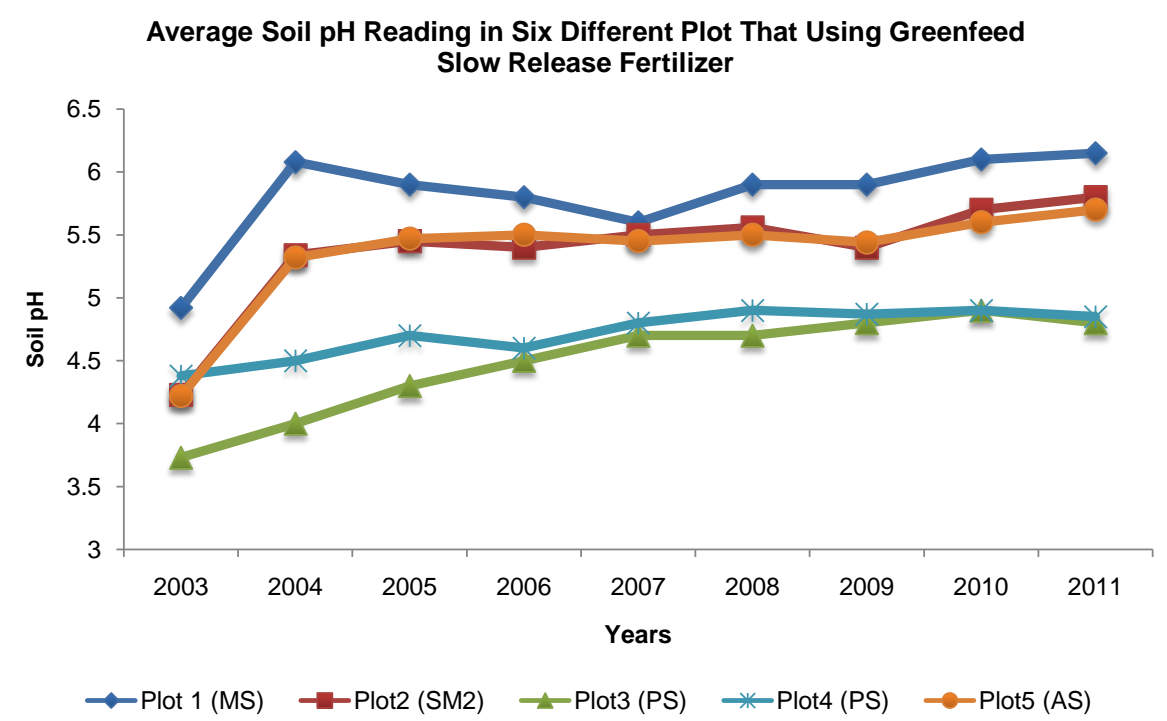

Figure 2. Average soil pH in six different plots that using Greenfeed ${ }^{\circledR}$ Slow Release Fertilizer.

salt accumulation in the subsurface soil or root zone may offer a reduced salt stress on plants. Thus, an application of zeolite may filter harmful salts from the root zone, thereby creating a favorable environment for plant growth and soil ecosystem.

\section{4. $\mathrm{H}_{2} \mathrm{O}$ Retainer}

Climate change especially rainfall becoming variable in worldwide regions and extreme weather is expected to increase abiotic and biotic stress on plants [27]. Soil moisture determines nutrients availability for plant uptake including ion transport, nutrient supply and uptake by plants is influenced by water content of a soil [28]. These mechanisms supply a significant proportion of nutrients that are present at high concentrations in soil solution or are almost exclusive in the 
Plant Available Water as Affected by Different Rates of Zeolites

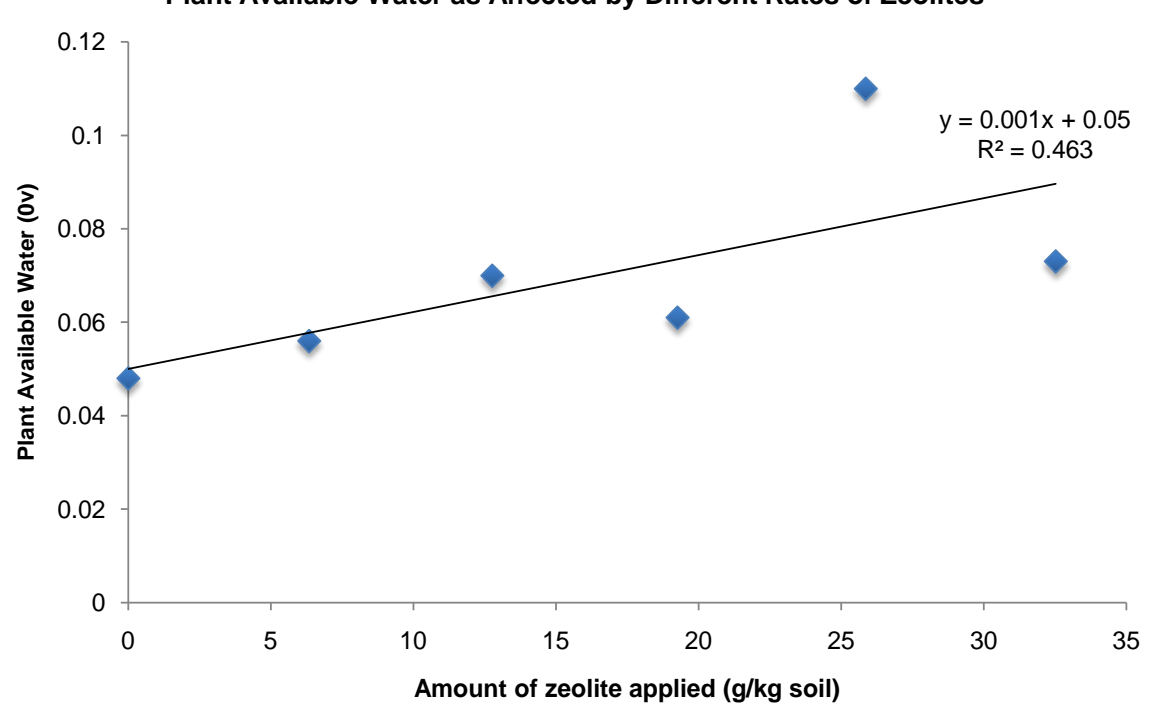

Figure 3. Plant available water as affected by different rates of zeolite.

solution phase in order for the nutrients to be taken up by the plant [29] [30].

Zeolites have been proposed to improve the water holding capacity and drainage control [31] [32] [33], eventually prevention on nutrient leaching. Figure 3 shows that for every gram of zeolite added to a kilogram of soil, there is a significant $0.12 \%$ increase in the plant available water [34]. Integrated zeolite inside Greenfeed ${ }^{\circledR}$ Slow Release Fertilizer has the ability to retain moisture is another positive aspect to be use as a soil amendment. Zeolites can hold up to $60 \%$ of their weight in water due to the high porosity of their crystalline structure [9] [10] [11]. Zeolite acts as a non-form changing, permanent water reservoir, which provides prolonged moisture during dry periods as well as promoting rapid re-wetting and improved lateral spread in the root zone during irrigation. This in turn reduces the quantities of water needed for irrigation [9] [10] [11].

\section{Conclusion}

Commercial slow release fertilizer from Greenfeed ${ }^{\circledR}$ has demonstrated various advantages over past decades in many crops. The mechanisms involved in the product action can be summarized into characteristics as ion-gradient reservoir, $\mathrm{pH}$ balancer and water retainer. During nutrient release, it is released based on ionic gradient difference between the fertilizer and the soil. This will ensure that the nutrient released is being carried out synergistically to the soil environment. GSRF displays a slight-alkaline characteristic that has the ability to improve the soil $\mathrm{pH}$ around the applied area. By using of GSRF, soil pH was gradually improved. Application of GFSF may filter harmful salts from the root zone, thereby creating a favorable environment for plant growth and soil ecosystem. Zeolites integrated GSRF has the ability to retain moisture which is another positive aspect to be used as a soil amendment. With these mentioned mechanisms occurred during its application, we hope this may interpret clearly for its further promotion and po- 
pularization in other regions.

\section{References}

[1] Huang, J., Xu, C.C., Ridoutt, B.G., Wang, X.C. and Ren, P.A. (2017) Nitrogen and Phosphorus Losses and Eutrophication Potential Associated with Fertilizer Application to Cropland in China. Journal of Cleaner Production, 159, 171-179. https://doi.org/10.1016/j.jclepro.2017.05.008

[2] Zhang, B.G., Cao, J., Zhang, C.Y., Song, Z., Zhang, F.S. and Chen, X.P. (2017) Reducing Nitrogen Leaching in a Subtropical Vegetable System. Agriculture, Ecosystems and Environment, 241, 133-141. https://doi.org/10.1016/j.agee.2017.03.006

[3] Hegedus, M., Toth-Bodrogi, E., Nemeth, S., Somlai, J. and Kovacs, T. (2017) Radiological Investigation of Phosphate Fertilizers: Leaching Studies. Journal of Environmental Radioactivity, 173, 34e-43e. https://doi.org/10.1016/j.jenvrad.2016.10.006

[4] Yang, X.D., Jiang, R.F., Lin, Y.Z., Li, Y.T., Li, J. and Zhao, B.Q. (2017) Nitrogen Release Characteristics of Polyethylene-Coated Controlled-Release Fertilizers and Their Dependence on Membrane Pore Structure. Particuology, 36, 158-164. https://doi.org/10.1016/j.partic.2017.05.002

[5] Chowdhury, S., Khan, N., Kim, G.H., Harris, J., Longhurst, P. and Bolan, N.S. (2016) Zeolite for Stripping from Farm Effluents. In: Prasad, M.N.V. and Shih, K., Eds., Environmental Materials and Waste, Academic Press, 569-589. http://dx.doi.org/10.1016/B978-0-12-803837-6.00022-6

[6] Peres-Caballero, R., Gil, J. and Gondalez, J.L. (2008) The Effect of Adding Zeolite to Soils in Order to Improve the N-K Nutrition of Olive Trees. American Journal Agriculture Biological Science, 2, 321-324.

[7] Inglezakis, V.J., Loizidou, M.D. and Grigoropoulou, H.P. (2002) Equilibrium and Kinetic Ion Exchange Studies of $\mathrm{Pb}^{2+}, \mathrm{Cr}^{3+}, \mathrm{Fe}^{3+}$, and $\mathrm{Cu}^{2+}$ on Natural Clinoptilolite. Water Research, 36, 2784-2792. https://doi.org/10.1016/S0043-1354(01)00504-8

[8] Gruener, J.E., Ming, D.W., Henderson, K.E. and Galindo, C. (2003) Common Ion Effects in Zeoponic Substrates: Wheat Plant Growth Experiment. Microporous and Mesoporous Materials, 61, 223-230. https://doi.org/10.1016/S1387-1811(03)00371-8

[9] Latifah, O., Ahmed, O.H. and Majid, N.M.A. (2017) Enhancing Nitrogen Availability from Urea Using Clinoptilolite Zeolite. Geoderma, 306, 152-159. https://doi.org/10.1016/j.geoderma.2017.07.012

[10] Ramesh, K. and Reddy, D.D. (2011) Zeolites and Their Potential Uses in Agriculture. Advances in Agronomy, 113.

[11] Tsintskaladze, G., Eprikashvili, L., Mumladze, N. Gabunia, V., Sharashenidze, T., Zautashvili, M., Kordzakhia, T. and Shatakishvili, T. (2017) Nitrogenous Zeolite Nanomaterial and the Possibility of Its Application in Agriculture, Annals of Agrarian Science, 15, 365-369. https://doi.org/10.1016/j.aasci.2017.07.006

[12] Ng, C.C., Wu, S.J., Asyraf, M. and Tan, Y.W. (2016) Effects of Novel Slow Release Fertilizer on Banana Foliar Nutrients, Photosynthetic Rate, Chlorophyll Content, Yield and Fruit Quality. Hans Journal of Agricultural Sciences, 6, 49-56. https://doi.org/10.12677/HJAS.2016.63008

[13] Ng, C.C., Wu, S.J., Asyraf, M., Khairuddin, M.I. and Tan, Y.W. (2016) Effects of Novel Zeolite Fertilizer on the Harvesting Quality and Yield of Paddy. Hans Journal of Agricultural Sciences, 6, 79-86. https://doi.org/10.12677/HJAS.2016.63012

[14] Lateef, A., Nazir, R., Jamil, N., Alam, S., Shah, R., Khan, M.N. and Saleem, M. 
(2016) Synthesis and Characterization of Zeolite Based Nanoecomposite: An Environment Friendly Slow Release Fertilizer. Microporous and Mesoporous Materials, 232,174-183. https://doi.org/10.1016/j.micromeso.2016.06.020

[15] Ok, C.H., Anderson, S.H. and Ervin, E.H. (2003) Amendments and Construction Systems for Improving the Performance of Sand-Based Putting Greens. Agronomy Journal, 95, 1583-1590. https://doi.org/10.2134/agronj2003.1583

[16] Abdi, G.H., Khui, M.K. and Eshghi, S. (2006) Effects on Natural Zeolite on Growth and Flowering on Strawberry. International Journal of Agricultural Research, 1, 384-389. https://doi.org/10.3923/ijar.2006.384.389

[17] DeSutter, T.M. and Pierzynski, G.M. (2005) Evaluation of Soils for Use as Liner Materials: A Soil Chemistry Approach. Journal of Environmental Quality, 34, 951962. https://doi.org/10.2134/jeq2004.0295

[18] Aghaalikhani, M., Gholamhoseini, M., Dolatabadian, A., Khodaei-Joghan, A. and Sadat, A.K. (2012) Zeolite Influences on Nitrate Leaching, Nitrogen-Use Efficiency, Yield and Yield Components of Canola in Sandy Soil. Achieve in Agronomy Soil Science, 58, 1146-1169. https://doi.org/10.1080/03650340.2011.572876

[19] Bley, H., Gianello, C., Santos, L.S. and Selau, L.P.R (2017) Nutrient Release, Plant Nutrition, and Potassium Leaching from Polymer-coated Fertilizer. Revista Brasileira de Ciência do Solo, 41, e0160142. https://doi.org/10.1590/18069657rbcs20160142

[20] Zareabyaneh, H. and Bayatvarkeshi, M. (2015) Effects of Slow-release Fertilizer on Nitrate Leaching, Its Distribution in Soil Profile, N-Use Efficiency, and Yield in Potato Crop. Environmental Earth Sciences, 74, 3385-3393. https://doi.org/10.1007/s12665-015-4374-y

[21] Raven, J.A. and Smith, F.A. (1976) Nitrogen Assimilation and Transport in Vascular Land Plants in Relation to Intracellular pH Regulation. New Phytologist, 76, 415-431. https://doi.org/10.1111/j.1469-8137.1976.tb01477.x

[22] Foong, S.F. (1993) Potential Yield of Irrigated Oil Palm. Indian Oil Palm Journal, 3, 8-20.

[23] Kim, Y.S., Reid, F., Hansen, A. and Zhang, Q. (2000) On-Field Crop Stress Detection System Using Multi-Spectral Imaging Sensor. Agricultural Biosystems Engineering, 1, 88-94.

[24] Brix, H., Dyhr-Jensen, K. and Lorenzen, B. (2002) Root-Zone Acidity and Nitrogen Source Affects Typha latifolia L. Growth and Uptake Kinetics of Ammonium and Nitrate. Journal of Experimental Botany, 53, 2441-2450. https://doi.org/10.1093/jxb/erf106

[25] Raven, J.A. (1986) Biochemical Disposal of Excess $\mathrm{H}^{+}$in Growing Plants? New Phytologist, 104, 175-206. https://doi.org/10.1111/j.1469-8137.1986.tb00644.x

[26] Kočí, V. (1997) Screening of the Effect of Several Cations Forms Extracts of Synthetic Zeolite 4A. Vod. Hospod., 47, 213-215. (In Czech)

[27] IPCC (2013) Climate Change 2013: The Physical Science Basis. Intergovernmental Panel on Climate Change.

[28] Bardgett, R.D. and Wardle, D.A. (2010) Aboveground-Belowground Linkages: Biotic Interactions, Ecosystem Processes, and Global Change. Oxford University Press, Oxford.

[29] Brockett, B.F.T., Prescott, S.J. and Grayston, S.J. (2012) Soil Moisture Is the Major Factor Influencing Microbial Community Structure and Enzyme Activities across Seven Biogeoclimatic Zones in Western Canada. Soil Biology and Biochemistry, 44, 
9-20. https://doi.org/10.1016/j.soilbio.2011.09.003

[30] Meisnera, A., De Deyn, G.B., de Boer, W. and van der Putten, W.H. (2013) Soil Biotic Legacy Effects of Extreme Weather Events Influence Plant Invasiveness. Proceedings of the National Academy of Sciences, 110, 9835-9838.

https://doi.org/10.1073/pnas.1300922110

[31] Huang, Z.T. and Petrovic, A.M. (1994) Clinoptilolite Zeolite Influence on Nitrate Leaching and Nitrogen Use Efficiency in Simulated Sand Based Golf Greens. Journal of Environmental Quality, 23, 1190-1194. https://doi.org/10.2134/jeq1994.00472425002300060009x

[32] He, X.B. and Huang, Z.B. (2001) Zeolite Application for Enhancing Water Infiltration and Retention in Loess Soil. Resources, Conservation and Recycling, 34, 45-52. https://doi.org/10.1016/S0921-3449(01)00094-5

[33] Bigelow, C.A., Bowman, D.C. and Cassel, D.K. (2004) Physical Properties of Three Sand Size Classes Amended with Inorganic Materials or Sphagnum Peat Moss for Putting Green Rootzones. Crop Sciences, 44, 900-907. https://doi.org/10.2135/cropsci2004.9000

[34] Makungwe, M. (2014). Evaluation of the Potential of Zeolite as a Soil Conditioner for Two Zambian Soil. Master's Thesis, The University of Zambia, Lusaka. 